\title{
OPERATION OF A PUBLIC GEOLOGIC CORE AND SAMPLE REPOSITORY IN HOUSTON, TEXAS
}

\section{$\underline{\text { Technical Progress Report }}$}

Reporting Period April 15, 2004 - May 31, 2005

\author{
by \\ Scott W. Tinker \\ Director and Principal Investigator \\ Beverly Blakeney DeJarnett \\ Research Associate and HRC Curator \\ And \\ Laura C. Zahm \\ Research Associate and HRC Curator
}

April 2005

for

U.S. Department of Energy

Award No. DE-FG26-02NT15290
Bureau of Economic Geology
John A. and Katherine G. Jackson School of Geosciences
The University of Texas at Austin
P.O. Box X, University Station
Austin, TX 78713-8924




\section{DISCLAIMER}

This report was prepared as an account of work sponsored by an agency of the United States Government. Neither the United States Government nor any agency thereof, nor any of their employees, makes any warranty, express or implied, or assumes any legal liability or responsibility for the accuracy, completeness, or usefulness of any information, apparatus, product, or process disclosed, or represents that its use would not infringe privately owned rights.

Reference herein to any specific commercial product, process, or service by trade name, trademark, manufacturer, or otherwise does not necessarily constitute or imply its endorsement, recommendation, or favoring by the United States Government or any agency thereof. The views and opinions of authors expressed herein do not necessarily state or reflect those of the United States Government or any agency thereof. 


\section{ABSTRACT}

The Bureau of Economic Geology's Houston Research Center (HRC) is well established as a premier regional research center for geologic research serving not only Houston, but geoscientists from around Texas, the U. S., and even the world. As reported in the 2003-2004 technical progress report to the DOE, the HRC provides a state-of-the-art core viewing facility, two fully equipped conference rooms, and a comprehensive technical library, all available for public use. In addition, the HRC currently houses over 500,000 boxes of rock material, and has space to hold approximately 400,000 more boxes. Use of the facility has continued to increase during this third year of operation; over the past twelve months the HRC has averaged approximately 200 patrons per month. This usage is a combination of individuals describing core, groups of geoscientists holding seminars and workshops, and various industry and government-funded groups holding short courses, workshops, and seminars.

The BEG/HRC secured several substantial donations of rock materials and/or cash during this operating period. All of these funds went directly into the endowment.

Outreach during 2004 and 2005 included many technical presentations and several publications on the HRC. Several field trips to the facility were held for geoscience professionals and grade school students alike.

Goals for the upcoming year involve securing more donations of rock material and cash in order to fully fund the HRC endowment. BEG will also 
continue to increase the number of patrons using the facility, and we will strive to raise awareness of the HRC's 100,000-volume geoscience technical library. 


\section{TABLE OF CONTENTS}

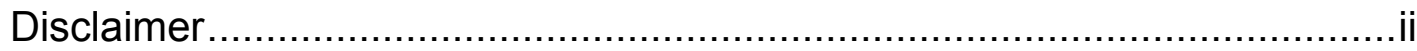

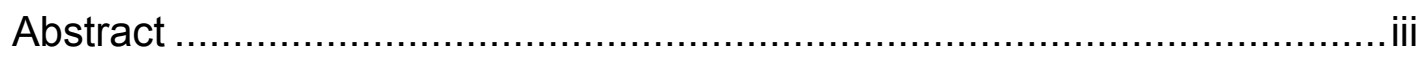

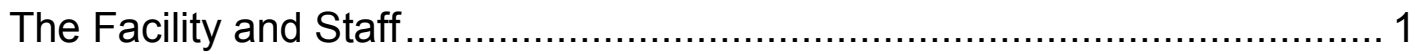

Equipment additions/upgrades................................................... 4

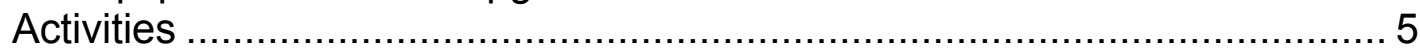

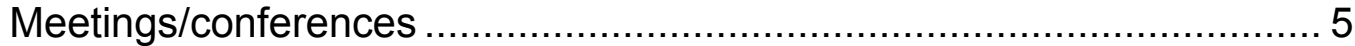

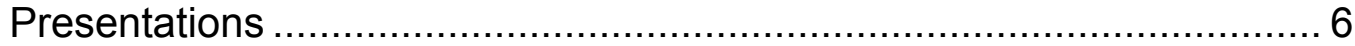

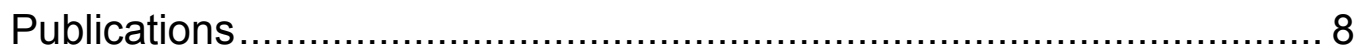

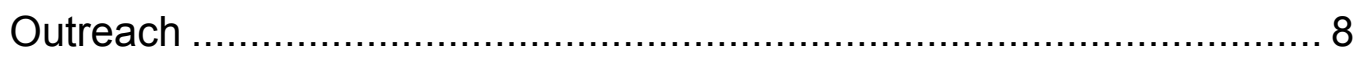

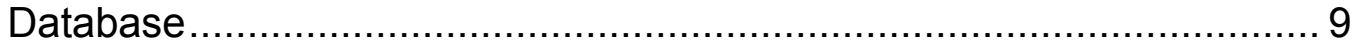

Goals for the upcoming Year $(2005-2006)$.......................................... 9 


\section{The Facility and Staff}

The Bureau of Economic Geology's Houston Research Center(HRC) is now established as a premier regional research center for geologic research serving not only Houston, but geoscientists from around Texas, the U. S., and even the world. As reported in the 2003-2004 technical progress report to the DOE, the HRC provides a state-of-the-art core viewing facility, two fully equipped conference rooms, and a comprehensive technical library, all available for public use. In addition, the HRC currently houses over 500,000 boxes of rock material, and has space to hold approximately 400,000 more boxes. Use of the facility has continued to increase during this third year of operation; over the past twelve months the HRC averaged approximately 200 patrons per month. This usage is a combination of individuals describing core, groups of geoscientists holding seminars and workshops, and various industry and government-funded groups holding short courses, workshops, and seminars.

The official Grand Opening of the HRC took place on June 4, 2004. More than 210 people attended the dedication ceremony hosted by Dr. Scott W. Tinker, Director of the BEG and State Geologist. 


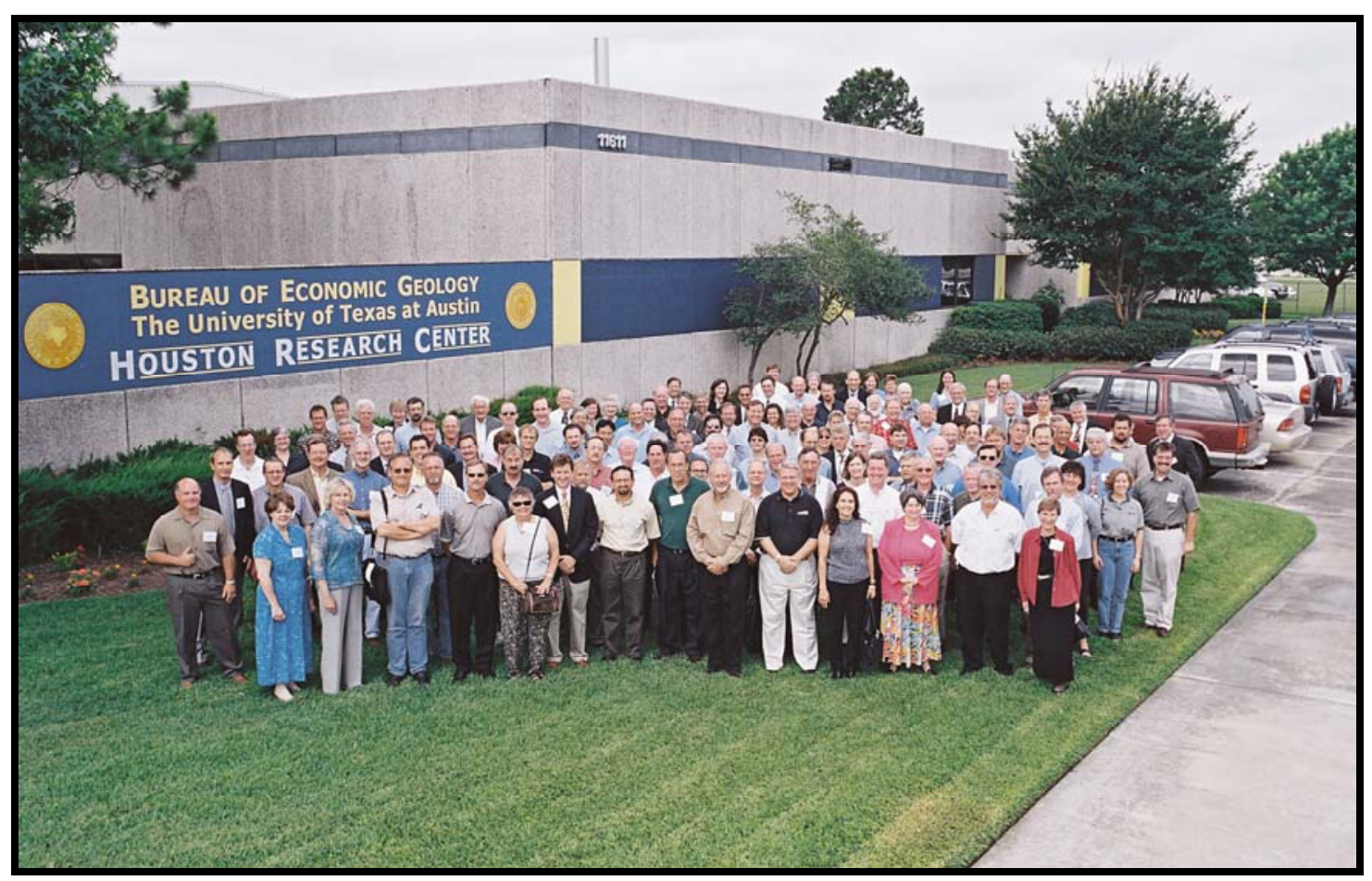

Distinguished speakers from Shell, BP, Marathon, Oxy Permian Ltd., Unocal, The United States Department of Energy, and the National Science Foundation participated in the ceremony. These companies and government entities have donated cores, samples, and technical literature to, and/or provided financial support for, the HRC.

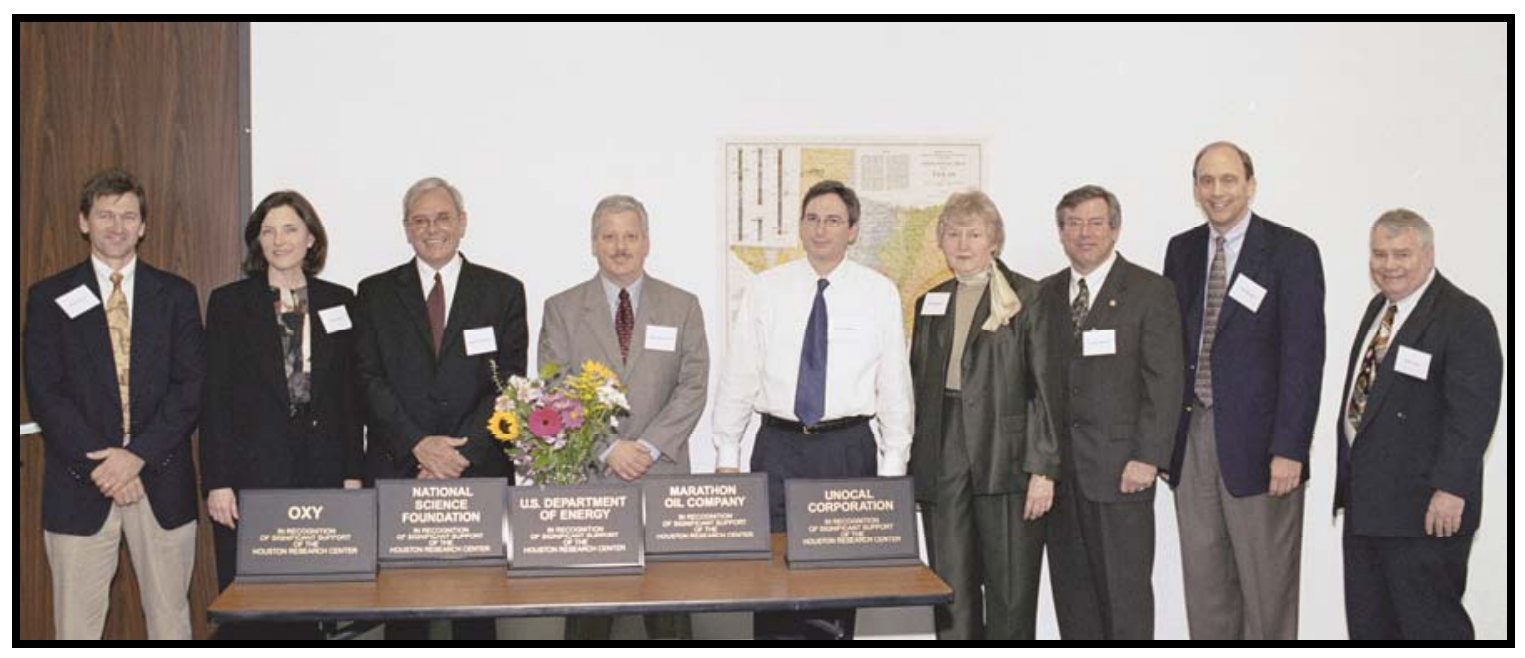


There are currently six people on staff at the HRC. Two part-time geologists curate the material and provide technical support to patrons. As of May 2005 there will be one part-time geologist/curator at the facility. Three fulltime warehouse staff coordinate all logistics of operating the entire facility and handle patrons requests for rock material. Marie Cassens, a full-time professional librarian was hired in March 2005 to oversee the technical library. The previous part-time librarian (Phyllis Vicars) left the HRC in October 2004 when her husband took a job in Austin, TX.

Major Donations to BEG/HRC (from April 2004-May 2004)

The BEG/HRC has secured several major donations of rock material and cash during 2004 and 2005. These funds go directly into the BEG/HRC endowment established to ultimately fund the facility and its operations off of the interest earned in the endowment.

- July 2004 - XTO Energy of Fort Worth, TX donated their complete collection of rock material, as well as an accompanying cash donation, to the BEG/HRC.

- July 2004 - The Gulf Coast Section of SEPM made a cash donation of $\$ 5000.00$ to the BEG/HRC.

- February 2005 - Kerr McGee donated several thousand boxes of rock material with an accompanying cash donation.

- April 2005 - Anadarko, Apache and Merit Oil made a joint donation of rock material and cash to the BEG/HRC. 


\section{Equipment Upgrades and Additions}

The following list summarizes equipment upgrades and additions that were made at the HRC from April 2004 to May 2005.

\section{Equipment Upgrades and Additions}

May 2004 - Refurbished two extremely high quality petrographic microscopes and five binocular microscopes that were donated to the HRC.

June 2004 - Received forklift as donation.

June 2004 - Received additional binocular microscope as donation (needs $110 / 220 \mathrm{~V}$ transformer)

August 2004 - NSF purchased digital camera for HRC for patron use

December 2004 - Anadarko Petroleum Corporation donated rock crusher, transfer scope, and several binocular microscopes

February 2005 - Anadarko Petroleum Corp. donated 25 Sun workstations, 25 desktop computers and monitors, 25 laptops, and 5 printers to the BEG

March 2005 - Complete overhaul of original air conditioning and heating system for the library, office spaces, conference rooms, and core viewing room.

April 2005 - Triad Energy donated a microfiche reader to the HRC.

March through May 2005 - HRC establishing working "saw" room with two trim saws and rock crusher.

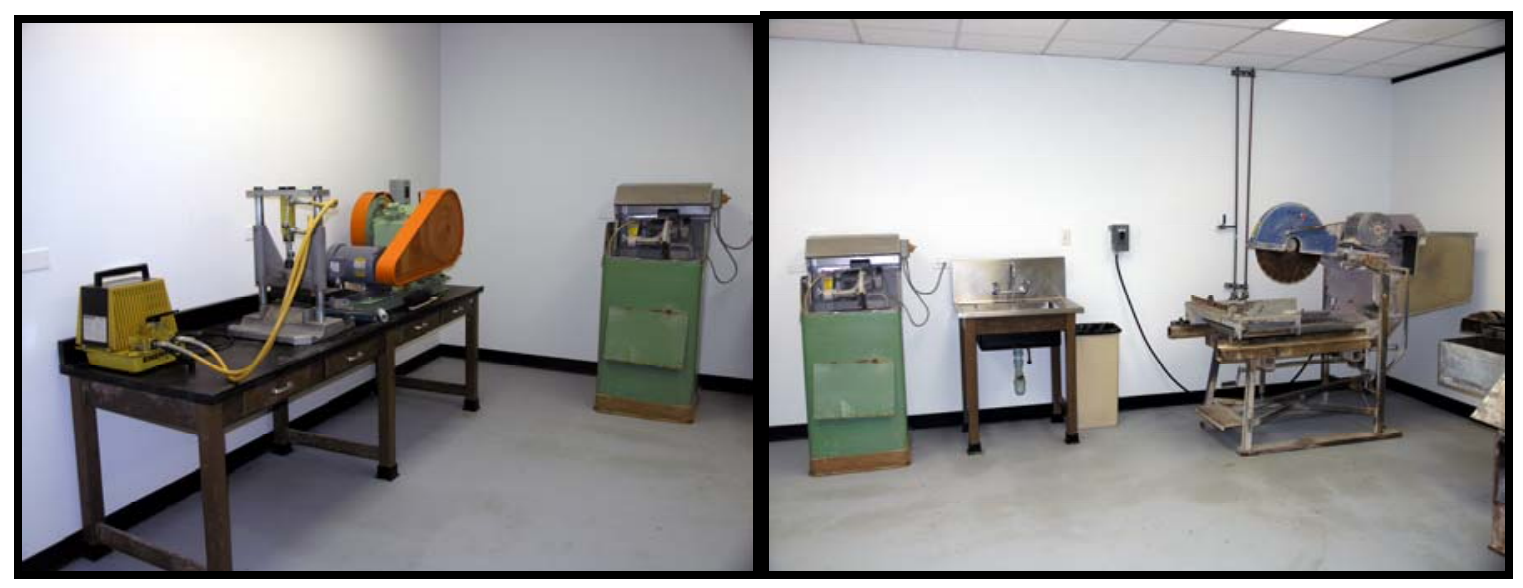




\section{HRC Activities}

\section{Selected Meetings/Conferences held at HRC (April 2004-May 2005)}

April 2004

- BEG Frio Brine Project, CO2 sequestration-Sue Hovorka (20 people)

May 2004

- HRC geologists led field trip at HRC for 40 middle school students

- Louisiana State University researchers here to describe core

- National Science Foundation-sponsored workshop on "Curation of Terrestrial Cores, Samples and other Scientific Collections" held at HRC (30 attendees)

June 2004

- Official HRC Grand Opening and Open House (200+ attendees)

- HRC geologists held field trip for 60+ children attending science camp

- Gulf Coast Carbon Consortium meeting

- PTTC workshop

- Nautilus USA week-long short course held here

August 2004

- Drilling Engineers Association Annual Meeting

- University of Kansas/Kansas Geological Survey meeting

- PTTC workshop

September 2004

- Eight different oil and gas companies utilized facility to view cores

- Geophysical short course for industry (led by Dr. R. Hardage)

- Gulf Coast Carbon Center meeting

October 2004

- Gulf Coast Carbon Center workshop

- DOE-sponsored workshop for CO2 sequestration

- ConocoPhillips core workshop

- University of Houston and Halliburton short course and core workshop

November 2004

- Houston Energy Council Meeting

- American Association of Petroleum Geologist Technical Planning Committee meeting

- Anadarko Petroleum Corp. core workshop

December 2004 
- Halliburton short course

- ConocoPhillips core workshop

- UNAVCO visits as part of NSF initiative to curate cores from Earthscope PBO project

- Petroleum Technology Transfer Council Seminar

January 2005

- Baker Energy holds 3-week training for ExxonMobil and Pride Energy

- Gulf Coast Carbon Center - 2 workshops

- AAPG Technical Planning Committee meeting for 2006 AAPG convention

February 2005

- Houston Geological Society all day short course (100 attendees)

- BEG Deep Shelf Gas Consortium meeting

- BEG ILRIS consortium meeting

March 2005

- AAPG Technical Planning Committee meeting for AAPG 2006 Convention

- Petroleum Technology Transfer Council seminar

- University of Houston-Halliburton core workshop

- Gulf Coast Section-SEPM meeting

- Louisiana State University researchers visit to view cores

April 2005

- PEICE one-week long geological short course

- ConocoPhillips New Hire Training

- ConocoPhillips core workshop

- Halliburton core workshop

May 2005

- Carbon Trading Credit Forum

- Baker Energy Workshop

- SEPM Planning Committee for 2006 AAPG

Number of participants in above events (as of 3-05)

Approximately 2470

\section{$\underline{\text { Technical Presentations }}$}

April 2004 - B. DeJarnett and L. Zahm co-authored poster session entitled "Cores and Cuttings - An Extraordinary Resource" at the National Meeting of the American Association of Petroleum Geologists, Dallas, TX. 
April 2004 - L. Zahm and B. DeJarnett co-authored poster session entitled "Dramatic Carbonate Reservoir Facies Illustrated in Cores from the Bureau of Economic Geology's Teaching Collection" at the National Meeting of the American Association of Petroleum Geologists, Dallas, TX.

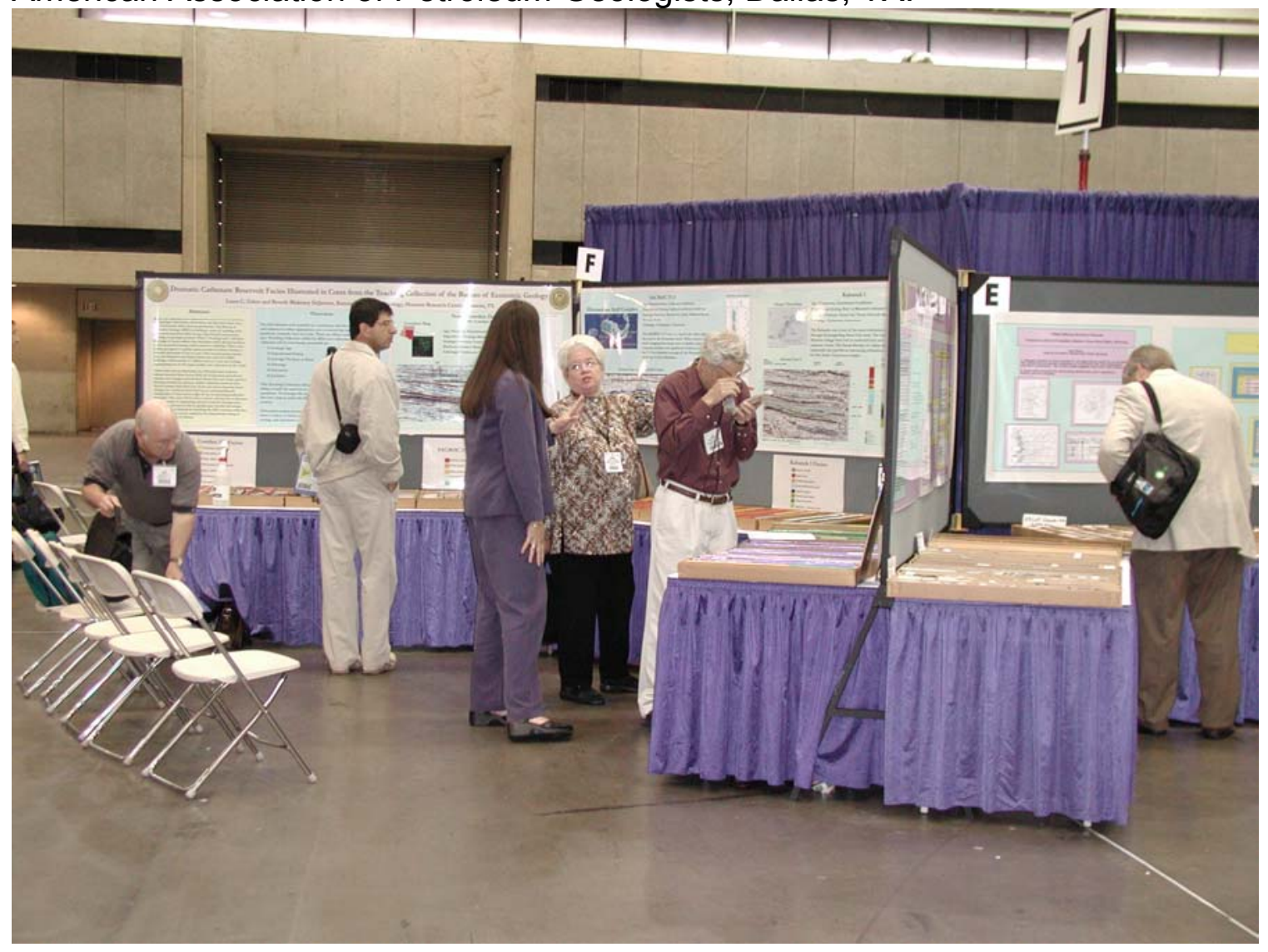

April $2004-\mathrm{L}$. Zahm and Scott Tinker made a presentation on the BEG and HRC to the AAPG Core and Sample Preservation Committee

June, 2004 - B. DeJarnett: "The Bureau of Economic Geology, University of Texas at Austin Core and Sample Repositories" for DOSECC (Drilling, Observation and Sampling of the Earth's Continental Crust) Annual Meeting, Rutgers University, Rutgers, NJ.

September, 2004 - Invited speaker - B. DeJarnett: "The Bureau of Economic Geology, University of Texas at Austin Core and Sample Repositories" $-5^{\text {th }}$ International Meeting, National Geoscience Data Repositories, USGS, Reston, $\mathrm{VA}$,

May 2004 - B. DeJarnett and L. Zahm: "The Houston Research Center - its Mission and History". National Science Foundation Workshop on "Curation of Terrestrial Cores, Samples and Collections", held at Houston Research Center. 


\section{Publications}

Blakeney DeJarnett, B and Zahm, L. C, 2004, Cores and Cuttings - An Extraordinary Resource. Abstr., American Association of Petroleum Geologists Annual Meeting, Dallas, TX, April, 2004.

Zahm, L. C. and Blakeney DeJarnett, B. B, 2004, Dramatic carbonate reservoir facies illustrated in cores from the teaching collection of the Bureau of Economic Geology. Abstr., American Association of Petroleum Geologists Annual Meeting, Dallas, TX, April, 2004.

Fisher Mallick, J. Blakeney DeJarnett. B. and L. C. Zahm, 2004, Big Rocks Founds in Houston. Houston Geological Society Bulletin, vol. 47, issue11, September 2004, p. 66-67.

\section{Outreach}

May $2004-$ B. DeJarnett and L. Zahm led field trip to the HRC for forty-eight $4^{\text {th }}$ and 5th graders from St. Rose Intermediate School in Houston, TX.

June 2004 - Led field trip for Conroe First Baptist Church Summer Science Campers (seventy-six kindergarteners through $5^{\text {th }}$ graders) at HRC

September $2004-\mathrm{L}$. Zahm organized and staffed a booth for 3 days at the Annual Houston Gem and Mineral Show, Houston, TX "The role of the petroleum industry in our lives and how an oil company utilizes core material" Over 3,000 students of all ages and their families attended

October 2004 - L. Zahm displayed several core examples to highlight the public collection of rock material at the Bureau of Economic Geology booth at the GCAGS Annual meeting in San Antonio, TX

February $2005-B$. DeJarnett spoke to all of $3^{\text {rd }}$ grade (120 students) at Coulson Tough K-6, The Woodlands, TX on "The Importance of Geology and Earth Science in our Everyday Lives"

February 2005 - Laura Zahm spoke to several preschools on Earth Science, Fossils, and Dinosaurs

March $2005-B$. DeJarnett spoke to all of $5^{\text {th }}$ grade (150 students) at Coulson Tough K-6, The Woodlands, TX on "The Importance of Geology and Earth Science in our Everyday Lives"

April $2005-L$. Zahm was an invited speaker to the $8^{\text {th }}$ grade career fair $(400$ students) at Beck Junior High School, Katy, TX on "Career opportunities in the Earth Sciences" 


\section{Database Update}

Continual progress being made in configuring our database to be compatible with the Geoinformatics initiative

Continuing to improve the internal data quality in our database (John Els, Laura Zahm, B. DeJarnett)

Continuing to move toward a GIS-driven database (J. Kipper, John Els, David Jordan, L. Zahm, B. DeJarnett)

\section{Goals for the Upcoming Year (2005-2006)}

Goals for the fourth year of operation include building the endowment until the majority of funds needed to fully fund the endowment are in place. Discussions with three large companies are very far along, and we expect to receive in excess of 450,000 boxes of donated rock material (equaling approximately $\$ 3.6$ million dollars) in 2005-2006. If we succeed in securing these donations, the BEG/HRC endowment would be fully funded and allowed to grow, and the HRC would be able to operate off of the interest generated from this endowment in approximately three years.

The BEG/HRC expects to receive its first shipment of cores from an NSFfunded project in mid to late-2005. An HRC advisory council is currently being formed under the provision required in the NSF contract that supports the HRC as the national repository for Terrestrial Cores, Cuttings and Samples. 
Goals for the HRC Technical Library include continuing to catalog all uncataloged materials with the ultimate goal of having the collection online and searchable by the geoscience community at large. Our professional librarian will also be striving to raise awareness of the library just as the two geologists have been successful in dramatically increasing the usage of the HRC for geoscientists conducting research and training.

The BEG greatly appreciates the support of the DOE in providing critical operational funds that have allowed the facility not only to be saved from loss for the scientific and academic community, but also to thrive and operate in the public domain well into the future. 